\title{
IMPLEMENTASI SISTEM INFORMASI MANAJEMEN DALAM KEAMANAN PENGOLAHAN DATA ORGANISASI
}

\author{
OLEH
}

\author{
HAFIZ AL GHIFARY
}

NIM

17002086

UNIVERSITAS NEGERI PADANG

EMAIL :

Alhafiz1221@gmail.com

\begin{abstract}
ABSTRAK
Pengolahan data dilakukan secara sederhana dimana data tersebut hanya disimpan dalam perangkat komputer atau disebut software. Dalam artikel ini sistem informasi manajemen bertujuan untuk mengelola keamanan data organisasi agar tidak disalahgunakan atau di plagiatkan oleh pihak-pihak yang tidak bertanggung jawab. Sistem informasi manajemen perlu dilakukan dalam pengambilan keputusan yang membutuhkan pemahaman tentang permasalahan dan pengetahuan mengenai alternatif pemecahannya. Manfaat dalam pengambilan keputusan dan identifikasi alternatif keputusan untuk memecahkan masalah, tujuan serta implementasi dari keamanan pengolahan data organisasi perlu dilakukan agar tidak terjadi kekeliruan nantinya.
\end{abstract}

Kata Kunci : Sistem informasi manajemen, keamanan, pengolahan data dan organisasi 


\section{PENDAHULUAN}

Sistem informasi manajemen pada saat ini sangat berperan penting dalam menjalankan suatu aktivitas baik itu di instansi maupun dalam lembaga pendidikan. Sejalan dengan perkembangan zaman saat ini maka semakin pesat pula perkembangan ilmu pengetahuan dan teknologi dalam memberikan informasi baik itu secara cepat, tepat dan akurat pada suatu organisasi ataupun dalam pendidikan yang harus bisa menerapkan sistem informasi berupa komputerisasi sebagai sarana dalam mengatasi masalah- masalah dalam keamanan pengolahan data organisasi. Dapat kita lihat dengan ketidak hati-hatian kita dalam mengelola data informasi tersebut, banyak data itu hilang dan tidak tersimpan atau tidak terdata dengan baik. Kekurangan dalam hal penyimpanan, pengelolaan, serta penyampaian informasi yang terjadi dalam kegiatan disekolah seperti data siswa, data guru, nilai siswa ataupun penjadwalan mata pelajaran siswa yang sering kali terjadi kerangkapan data karena data yang sudah diolah tidak terorganisasikan dengan baik. Tidak hanya itu data informasi tersebut bisa dimanipulasi oleh pihak lain dengan sengaja dilakukan serta tidak adanya keamanan dalam penyimpanan data serta kurangnya perhatian para ucer dalam mengelola dan mengamankan data nya sehingga terjadilah manipulasi data dan sebagainya.

Dengan permasalahan yang ada maka diperlukannya sebuah solusi untuk mengatasi permasalahan tersebut. Dengan begitu dapat dirumuskan masalah yang akan dihadapi yaitu bagaimana mengimplementasikan sistem informasi manajemen ini dalam keamanan mengelola data sebuah organisasi, perusahaan ataupun dalam dunia pendidikan.

Jadi tujuan dari penulisan artikel ini ialah agar kita tahu cara untuk menerapkan atau mengimplementasikan sistem informasi manajemen ini untuk keamanan dalam pengolahan data organisasi, perusahaan maupun dalam dunia pendidikan. 


\section{PEMBAHASAN}

\section{Ringkasan Artikel}

\section{A. Pengertian sistem informasi manajemen}

Sistem informasi merupakan sebuah gabungan komponen-komponen yang saling bekerja sama dalam mengumpulkan data, memproses data menyimpan data dan menyebarkan data informasi tersebut untuk pengambilan sebuah keputusan, kontrol, analisis dan visualisasi data didalam organisasi.

Menurut (Agustiandra \& Sabandi, 2019) Sistem informasi manajemen adalah sebuah metode yang digunakan oleh pemakai informasi untuk mengelola data, baik itu data berupa data siswa maupun data guru yang akan menjadi sebuah informasi yang kemudian hasil dari informasi tersebut kemudian dijadikan sebagai bahan pertimbangan dalam sebuah proses pengambilan keputusan.

Sistem informasi manajemen adalah jaringan prosedur pengelolaan dari mulai 1) pengumpulan data, 2) pengolahan data, 3) penyimpanan data, 4) pengambilan data, 5) penyebaran informasi dengan menggunakan berbagai peralatan yang tepat, dengan maksud memberikan data kepada manajemen setiap waktu diperlukan dengan cepat dan tepat untuk dasar pembuatan keputusan dalam rangka mencapai tujuan organisasi (Zakia, 2019).

Jadi dapat disimpulkan bahwa sistem informasi manajemen adalah suatu metode yang digunakan oleh pemakai informasi / Ucer yang mana informasi itu berupa pengelolaan pengumpulan, pengolahan penyimpanan, pengambilan data dan penyebaran informasi menggunakan berbagai peralatan yang tepat yang kemudian dijadikan sebagai bahan pertimbangan dalam sebuah proses pengambilan keputusan. 


\section{B. Manfaat Sistem Informasi Manajemen}

Menurut (Tata Sutabri, 2005:107) Nilai dari informasi yang dihasilkan dari penggunaan computer dalam sistem informasi manajemen memang sulit untuk dihitung dengan uang. Akan tetapi hal tersebut dapat membantu menetapkan perkiraan nilai tersebut sebagai berikut:

1) Dapat diperoleh (availabirity) yaitu mendapat informasi yang semula atau sebelumnya tidak dapat diperoleh.

2) Ketetapan waktu (timelines) yaitu informasi yang dihasilkan oleh komputer dapat diperoleh dalam waktu yang cepat dan tepat.

3) Ketelitian (accuracy) yaitu informasi yang dihasilkan oleh komputer terjamin ketelitiannya.

4) Kelengkapan (completennes) yaitu informasi yang dihasilkan oleh komputer lebih lengkap dan lebih jelas.

5) Penyajian (presentation) yaitu informasi yang dihasilkan dari proses komputer dapat disajikan menurut selera pemakai informasi tersebut.

\section{Tujuan Sistem Informasi Manajemen}

Menurut (Gaol, 2008) tujuan dari suatu sistem informasi manajemen itu adalah memberikan informasi untuk pembuatan keputusan dalam merencanakan, memulai, mengatur dan mengendalikan operasi sub sistem dari organisasi, perusahaan ataupun disekolah dan juga memberikan sebuah sinergi dalam prosesnya.

Pengolahan data informasi adalah kegiatan masyarakat yang utama. Bagian yang terpenting dari pekerjaan seseorang adalah mencatat, mencari, dan menyerap informasi sebanyak mungkin, lenih kurangnya sekitar 80 persen waktu pencatatan seorang eksekutif bisa dihabiskan saat pemrosesan dan penyampaian 
informasi kepada orang lain. Komputer menjadi bagian yang terpenting dalam susunan pengolahan data informasi karena kuatnya pengaruh teknologi da nisi dari data yang akan diproses dan disampaikan nanti.

Jadi tujuan utama sistem informasi manajemen adalah membantu proses manajemen pada suatu organisasi. Manajemen meliputi seluruh hirarki kepengurusan dalam suatu organisasi secara keseluruhan hingga hirarki manajemen bahwa yang bertanggung jawab atas operasi sehari-hari dari organisasi tertentu.

\section{Implementasi Sistem Informasi Manajemen Terutama Dalam Keamanan Pengolahan Data Organisasi}

Sistem informasi merupakan suatu kebutuhan bagi organisasi dalam menjalankan aktivitasnya. Kelangsungan hidup organisasi sangatlah sulit tanpa penggunaan teknologi sistem informasi terutama dalam hal kemanan.

Keamanan data dan informasi merupakan hal yang sangat vital dalam sebuah organisasi karena informasi adalah aset penting bagi sebuah organisasi. Jika sistem informasi manajmen dapat diterapkan dengan baik disuatu perusahan maka akan mengurangi resiko dan semakin banyak data informasi yang disimpan tentu hal itu akan lebih rawan terjadi kerusakan.

Keamanan informasi akan diperoleh dengan mengimplementasi seperangkat alat kontrol yang layak, yang dapat berupa kebijakan-kebijakan, praktek-praktek, prosedur-prosedur, struktur-struktur organisasi dan perangkat lunak.

\section{Kajian Analitis}

1) Hasil survey ISBS (Information Security Breaches Survey) pada tahun 2000

Menunjukkan bahwa sebagian besar data atau informasi tidak cukup terpelihara/terlindungi sehingga beralasan kerawanan. 
2) Loudon (2008)

Sistem informasi dibangun oleh manajer unutk melayani kepentingan perusahaan, pada saat bersamaan organisasi harus waspada dan terbuka terhadap pengaruh sistem informasi untuk mendapatkan manfaat dari teknologi baru.

3) Kesimpulan

Sistem informasi merupakan aset penting bagi perusahaan dan keamanan data adalah hal yang vital bagi perusahaan sehingga dalam hal Tersebut sangat dbuthkan teknologi sistem informasi mnajemen yang menjamin keamanan data didalamnya.

Penerapan sistem informasi manajemen dalam fungsinya menjaga kemananan dalam organisasi adalah dengan pengamanan data dan informasi melalui penyimpanan data secara komputerisasi yang lebih aman dari kerusakan dan pencurian data informasi dari pihak luar maupun dalam organisasi. Dengan adanya sisitem informasi juga akan mempermudah akses data kembali jika ada data lama yang dibutuhkan suatu saat nanti.

\section{PENUTUP}

Sistem informasi manajemen adalah suatu metode yang digukana oleh pemakai informasi atau user yang mana informasi tersebut berupa pengelolaan data, pengumpulan data, pengolahan data, penyimpanan data, pengambilan data dan penyebaran informasi menggunakan berbagai peralatan yang tepat kemudian dijadikan sebagai bahan pertimbangan dalam sebuah proses pengambilan keputusan.

Manfaat sistem informasi manajemen yaitu 1) dapat diperoleh (availabirity) yaitu mendapat informasi yang semula atau sebelumnya tidak dapat diperoleh, 2) ketetapan waktu (timelines) yaitu informasi yang dihasilkan oleh komputer dapat diperoleh dalam waktu yang cepat dan tepat, 3) ketelitian (accuracy) yaitu informasi yang dihasilkan oleh komputer terjamin ketelitiannya, 4) kelengkapan (completennes) yaitu informasi yang 
dihasilkan oleh komputer lebih lengkap dan lebih jelas, dan 5) penyajian (presentation) yaitu informasi yang dihasilkan dari proses komputer dapat disajikan menurut selera pemakai informasi tersebut.

Tujuan sistem informasi manajemen yaitu membantu proses manajemen pada suatu organisasi. manajemen meliputi seluruh hirarki kepengurusan dalam suatu organisasi secara keseluruhan hingga hirarki manajemen bahwa yang bertanggung jawab atas operasi seharihari dari organisasi.

Implementasi sistem informasi manajemen demi keamanan pengolahan data suatu organisasi yaitu mengatur akses kontrol dengan menggunakan pasword, Untuk lebih meningkatkan keamanan sistem informasi, proteksi dapat ditambahkan. Proteksi ini dapat berupa filter (secara umum) dan yang lebih spesifik adalah firewall. Filter dapat digunakan untuk memfilter e-mail, informasi, akses, atau bahkan dalam level package tertentu. Penangkal lainnya adalah untuk memproteksi sistem informasi adalah dengan memasang, meng-update terus anti virus.

Adapun saran yang dapat diberikan kepada pihak yang bersangkutan ialah diharapkan dapat membangun suatu sistem informasi yang efektif dan efisien juga bermanfaat bagi organisasi, perusahaan maupun organisasi pendidikan disuatu sekolah. Dalam menerapkan sistem informasi manajemen ini terletak pada stabilnya jaringan internet. Karena pada umunya internet sangat susah dijangkau pada tempat-tempat yeng terpencil dan kesulitan mengolah data tersebut. Oleh karena itu, dibutuhkannya solusi dan kebijakan yang lebih baik lagi kedepannya agar jaringan internet mudah dijangkau agar permasalahan tidak terjadi kedepannya lagi. 


\section{REFERENSI}

Gaol, C. L. (2008). Sistem Informasi Manajemen Pemahaman Dan Aplikasi. Jakarta: PT Grasindo.

Agustiandra, V., \& Sabandi, A. (2019). Persepsi Guru Terhadap Penerapan Sistem

Informasi Manajemen Akademik Di Sekolah Menengah Kejuruan (Smk) Negeri 3

Padang. Jurnal Bahana Manajemen Pendidikan, 8(I), 1-8. Retrieved from

http://ejournal.unp.ac.id/index.php/bahana/article/view/103704

F. Buidman, F. Arza (2013). Pendekatan Technology Acceptance Model Dalam

Kesuksesan Implementasi Sistem Informasi Manajamen Daerah. Jurnal Wahana Riset Akuntansi, 1(I), 87-110. Retrieved from

http://ejournal.fip.unp.ac.id/index.php/wra/article/view/2315

Sutabri, Tata. 2012. Konsep Sistem Informasi. Yogyakarta :CV ANDI Offset 